報殅

||l|||||||||||||||||

\title{
IFSA'97 に参加して
}

\section{井上博行* 愚井 且有*}

\section{1.はじめに}

1997 年 6 月 25 日から 28 日まで 7 th IFSA World Congress (IFSA'97)が開催されました。こ の会議は 2 年に一度行われる IFSA の国際会議で, 今回は東欧のチェコ共和国の百塔の街プラ八での 開催でした. 日本からプラ八までの直行便はなく, ヨーロッパの主な都市から乗り継いで行かなけれ ばなりません。私達は, 関空からアムステルダムを 経由してプラ八に入りました。

チェコは数年前までのチェコスロバキアで，隣 りのスロバキアと一緒の国でしたが，東欧革命後 それぞれ分かれました．革命後の混乱の中どのよ うになったか興味があったのですが，以外と西欧 化が進んでいるように思えました。聞くところに よると，チェコは旧共産圏の中ではわりと経済的 に成功しているようで，帰国後のニュースでは NATOの加盟が認められたと報じられています。 また，プラ八は他のヨーロッパの国々から飛行機 で2〜3 時間で来れるため, 非常にたくさんの観光 客が訪れていました。しかし, 失業率はまだ高いよ うで，スリなどの犯罪も多いと聞きました。

\section{2. 会議の様子}

さて，会議はUniversity of Economicsで行わ れました(写真 1). 場所は日本で売っていたプラ 八の観光地図にはぎりぎ載っていないところに ありましたが，15〜20 分くらい歩けば街の観光ス ポットに行けるところでした。

38 ケ国からの参加があり，国別の参加者を表 1 に示します。最も多いのは日本からの参加者でし たが，今回はヨーロッパでの開催でもありヨーロ ッパからの参加者が半数 (208 名)を占めました.

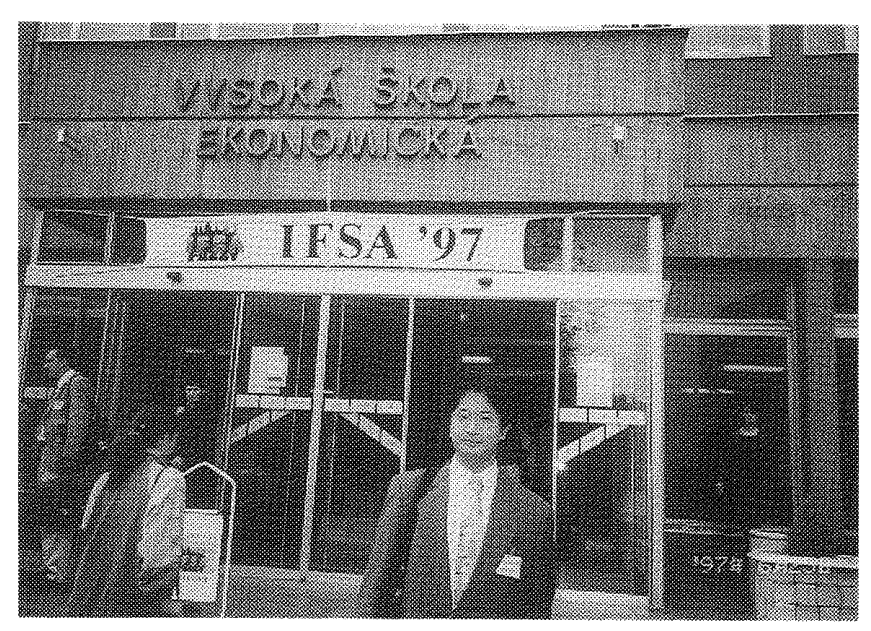

写真 | 会場前にて

表｜国別の参加者リスト

\begin{tabular}{lr|lr}
\hline 日本 & 65 & ロシア & 4 \\
チェコ & 50 & ハンガリー & 4 \\
アメリカ & 33 & インド & 4 \\
スペイン & 28 & スリエーデン & 3 \\
スロバキア & 21 & ポルトガル & 3 \\
ドイッ & 18 & イスラエル & 3 \\
イタリア & 17 & オーストラリア & 3 \\
台湾 & 16 & ブルガリア & 2 \\
韓国 & 14 & フィンランド & 2 \\
フランス & 12 & シンガポール & 2 \\
ブラジル & 12 & トルコ & 2 \\
ベルギー & 11 & オランダ & 1 \\
ポーランド & 11 & アゼルバイジャン & 1 \\
イギリス & 10 & デンマーク & 1 \\
カナダ & 10 & スロベニア & 1 \\
ユーゴスラビア & 8 & クロアチア & 1 \\
オーストリア & 5 & マケドニア & 1 \\
ルーマニア & 4 & ベラルーシ & 1 \\
イラン & 4 & 香港 & 1 \\
\hline 合計 & \multicolumn{2}{|l}{} \\
\hline
\end{tabular}


特に, 地元のチェコをはじめ東欧各国からの参加 (103名)が多くありました.

会議のプログラムは，4 日間で Invited Lecture が 8 件, パネルディスカッション,一般セッション および Invited セッションが 69 セッションが組 まれていました. Invited Lecture の内容は以下の 通りです。

- L.A. Zadeh: The theory of fuzzy information granulation and its centrality in fuzzy logic

- D.M. Gabbay: Fibring and labelling: two methods for making modal logic fuzzy

- K. Hirota: A proposal of knowledge base for multimedia intelligent communication system

- G.J. Klir: Uncertainty-based information: a critical examination

- R. Kruse, C. Borgelt: Learning possibilistic networks: data mining applications

- D. Mundici: Logic and computation of nonboolean partitions

- M. Vlach: Scheduling and sequencing in fuzzy environment

- P. Zlatos: The alternative set theory and fuzzy sets

特に, Opening Session(写真 2)の後, Zadeh 教 授はファジィと granulation(粒度)について熱心 に講演されていました(写真 3 ).

会場が大学の講義室を使っていたこともあり， 各セッションの講演では OHP だけでなく黒板ま で使って説明されている方もたくさんおられ，活 発な議論がなされてました.しかし,私が発表した Genetic Algorithms I はホームページや郵送され てきたプログラムと, 受付時にいただいた Final

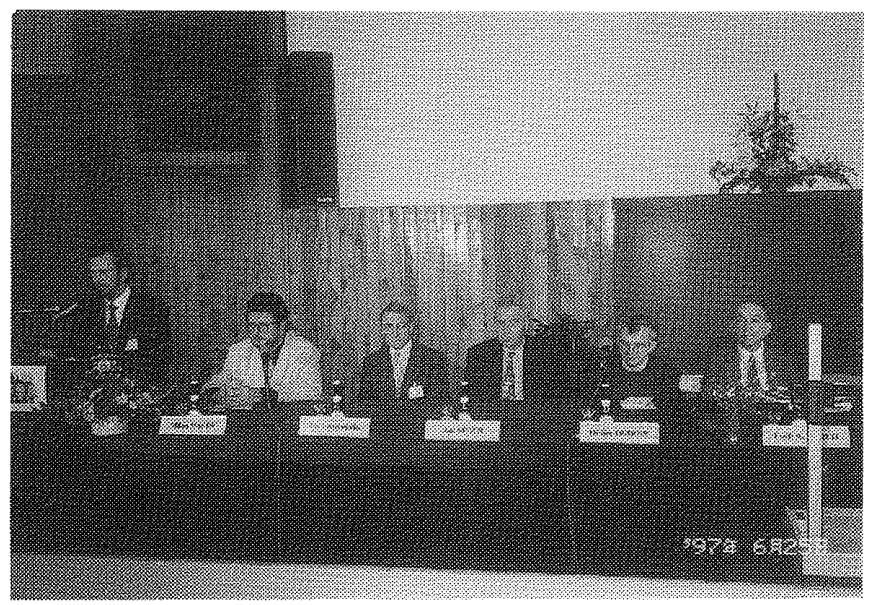

写真 2 Opening Session の様子
Program とでは発表時間も場所もアナウンスな しに変わっており，気がつかなければ志れるとこ ろでした、そのためか, 司会者が知らなかったよう で，会場に姿を見せられず，結局，1 st speakerの K. Zimmermann 氏がセッションの進行をされて ました。そのため, 私の発表に対しての質問は何も なく,何か拍子抜けという感じがしました. 関係者 に対し，変更のアナウンスをもう少し明確に伝え て欲しいと思いました。

\section{Welcome Party}

Welcome Party は, ヴァーツラフ広場の一角に あるレストランの最上階で行われ，立食形式でし た。また，テラスに出ることができ，プラ八の街並 みを見ながらのパーティでした(写真 4$)$ ．普通の

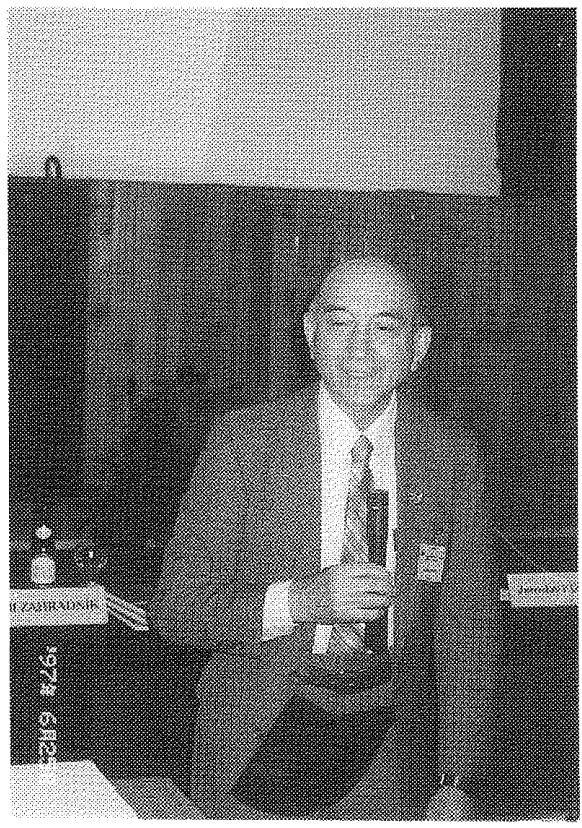

写真 3 Zadeh 教授の講演

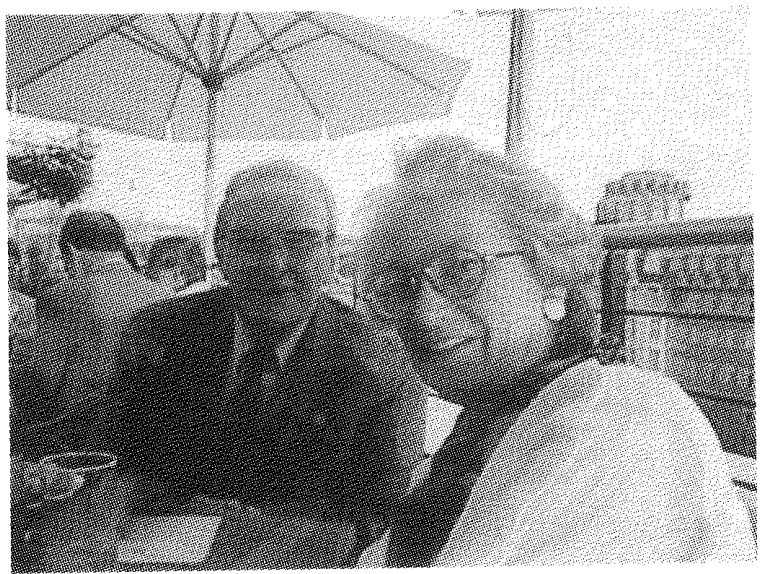

写真 4 Welcome Party にて (Crockett 教授夫妻) 
バンケットなら多くの方からのご挨拶があるので すが, さすがは音楽の町プラ八, Welcome Party では代わりにコンサートがありました. IIZUKA' 96 でも素晴らしいピアノを披露してくれた $\mathrm{M}$. Grabisch 氏のショパンをはじめ 7 組の演奏があ りました。いずれもハイレベルな演奏で, 素晴らし いものでした，私もオーケストラなどでトロンボ ーンをやっているので, 楽器を持ってきて参加し たくなりました。

また, Welcome Party 以外にいろいろな Social Program が用意されていましたが, 音楽のコンサ 一トも用意されていました.私達も, オルガンコン サートに行き，バッハからヤナーチェクの曲まで 10 曲程度を実際の教会のパイプオルガンを使っ て演奏されました。

\section{4. 音楽の町プラハ}

プラ八は百塔の街として有名ですが, 音楽が大 変盛んであるという側面も持っています。偉大な 作曲家もたくさん出ています。ドボルザークは,

「新世界」などが日本でもお馴染みです．国民的作 曲家スメタ十の我が祖国第 2 曲目「モルダウ」は, プラ八に流れるヴァルタヴァ川のことであり，第 1 曲目「高い城」はプラ八近郊にあるヴィシェフラ 一トというお城です。近世の作曲家としてヤナー チェクなども挙げられます。マーラーも若い頃こ の地で指揮者として活動しています.また，モーツ アルトが「ドン・ジョバンニ」を作曲したのはプラ 八です.昨年亡くなられたのですが，チェコ出身の 世界的指揮者であったクーべリックは，亡命して いたのですが, 1990 年のプラ八の春音楽祭で「我 が祖国」の指揮をし，人々に感銘を与えました。こ のようにウィーンやドイツに負けないくらい，音 楽の歴史を持っています。

プラ八では，毎晚のようにコンサートが開かれ ており，道を歩くとコンサートのビラがたくさん

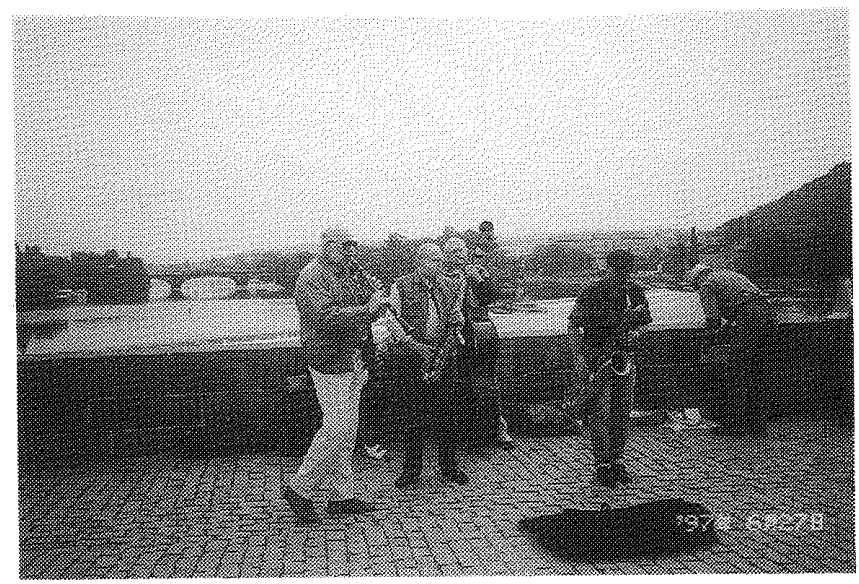

写真 5 カレル橋で演奏する楽団

もらえます。私達も，プラハ・モーツァルト・オー ケストラの演奏をドボルザークホールで聴くこと ができました.また, 毎年 5 月から 1 カ月くらいプ ラ八の春音楽祭が開かれており, 今年は井上道義 率いる京都市交響楽団が参加していました。会議 がもう 1 カ月早かったら聞けたのにと思うと残念 です。その他に, 街角で演奏されてる方もありまし た (写真 5).

このように，音楽の好きな私にとって十分に楽 しむことができました，今度はプライべートで来 て，音楽三昧の生活をしてみたいものです。

\section{5. おわりに}

本会議に出席して，ファジィのトップレベル研 究に触れることができ大変有意義でした，次回の 1999 年 (今世紀最後)の開催場所は, 台湾だそうで す.食べることに興味のある人は, 絶好の場所だと 思われます。

[問い合わせ先]

于 525 滋賀県草津市野路東 1-1-1

立命館大学理工学部情報学科亀井研究室 井上博行

TEL : 0775-61-2807

FAX : 0775-61-2669

Email : hiro@spice.cs.ritsumei.ac.jp 